\title{
SIR LUDWIG GUTTMANN
}

\author{
Professor V. PAeslack \\ President of the International Medical Society of Paraplegia
}

Sir Ludwig Guttmann, the Founder President of our Society and the Founder and Editor of Paraplegia, has completed his 8oth year. Those who do not know him and even those who do, are inclined to disbelieve this statement.

The special edition of the journal in 1969 was dedicated to an appreciation of the life work of this man, to whom work for the paraplegic owes its decisive impulse and who has become one of the most important starting points of modern rehabilitation in the whole world.

And now-is it really another Io years? Why does this time appear so short? I believe because the birthday child (and we with him) does not reflect on the past as a period of ageing contemplation but already thinks in terms of a further Io years full of intense activities, new ideas and inspirations. The therapeutic and rehabilitative principles developed by Sir Ludwig Guttmann have beyond all doubt and opposition been confirmed a thousandfold. His ideas have impregnated and stimulated the efforts of those who till the stony soil of rehabilitation.

With enviable creativity the 'old man' sees a résumé of his life's work not in a retrospective biography (for which we hope in the next decennium), but in a whole series of fundamental books and writings. To this end, however, he does not theorise endlessly behind his desk in Aylesbury-no, everywhere where something 'happens' in the field of paraplegia or of sport for the disabled we shall find Sir Ludwig an interested participant, a critical discussant and at times an outspoken fighter.

The International Medical Society of Paraplegia wishes her Founder President, the journal Paraplegia and its Editor every success; and we, dear friend, are confident that it will remain like this in the future.

Health and strength for the next decennium with your friendship and advice in our work; this meaningful life and its rich harvest is only granted to few people. We salute the youthful 'senior' of our Society in gratitude and admiration in the words of his own writing: ' . . . with what pride and satisfaction is he rewarded and with what priceless treasures is the community enriched!' 